\title{
Lise Öğrencilerinin Öznel İyi Oluşları ile Ahlâkî Olgunluk Seviyeleri Arasındaki İlişkinin İncelenmesi ${ }^{1}$
}

\author{
Arş. Gör. Çiğdem DEMİR ÇELEBI** \\ Marmara Üniversitesi, Atatürk Eğitim Fakültesi, Eğitim Bilimleri Bölümü, \\ Kadıköy / İstanbul / Türkiye
}

\section{Yrd. Doç. Dr. Osman SEZGİN}

Marmara Üniversitesi, Atatürk Eğitim Fakültesi, Eğitim Bilimleri Bölümü, Kadıköy / İstanbul / Türkiye

\section{$\ddot{\mathbf{O} z}$}

$\mathrm{Bu}$ araştırma, lise öğrencilerinin öznel iyi oluşları ile ahlâkî olgunluk seviyeleri arasındaki ilişkinin ortaya konması amacıyla gerçekleştirilmiştir. Araştırma, ilişkisel tarama modelinde kurgulanmış olup veriler Üsküdar ilçesinde öğrenim gören lise öğrencilerinden bizzat araştırmacı tarafından toplanmıştır. Elde edilen veriler SPSS 17.0 programı ile analiz edilerek tablolar hâlinde sunulmuştur. Analizlerde öznel iyi oluş ve ahlâkî olgunluğun yaş, cinsiyet, okul türü, sınıf seviyesi, öğrencinin hayatının

\footnotetext{
1 Bu araştırma Marmara Üniversitesi Bilimsel Araştırma Projeleri Birimi tarafından desteklenmiş olan C Tipi lisansüstü tez projeleri kapsamında hazırlanmıştır.

* Sorumlu Yazar. Tel: +905418587724 E-posta: cigdem.demircelebi@ gmail.com

(C) 2015 Kalem Eğitim ve Sağlık Hizmetleri Vakfi. Bütün Hakları Saklıdır. ISSN: 2146-5606
} 
çoğunu geçirdiği yer, annenin eğitim seviyesi, babanın eğitim seviyesi, öğrencinin ailesinin gelir seviyesi, annenin hayatta olma durumu ile babanın hayatta olma durumuna göre anlamlı farklılık gösterip göstermediği ile öznel iyi oluş ile ahlâkî olgunluk arasında anlamlı bir iliş̧ki olup olmadığı test edilmiştir.

Anahtar Kelimeler: Lise öğrencileri; Ahlâkî olgunluk; Öznel iyi oluş.

\title{
Relationship Between Subjective Well-Being and Moral Maturity Levels of High School Students
}

\begin{abstract}
This research was conducted to reveal the relationship between subjective well-being and moral maturity levels of high school students. The research was designed in relational screening model, and survey data was collected from students studying at high schools in Uskudar by the researcher. The data was analyzed by SPSS for Windows 17.0 statistic program, and submitted by tables. By the result of the study, it was tested if there were meaningful differences between subjective well being, moral maturity and age, gender, school type, class level, place the student has lived mostly, educational level of mother, educational level of father, income status of student's family, survival of mother, survival of father. It was also analyzed if there was any relationship between subjective well-being and moral maturity levels of high school students in Uskudar.
\end{abstract}

Keywords: High school students; Moral maturity; Subjective well-being.

\section{Extended Summary}

\section{Purpose}

In this study, the purpose was to explore the relationship between subjective well-being and moral maturity levels of high school students. The following questions were answered: 
1. What are the subjective well-being levels of high school students in Uskudar?

2. What are the moral maturity levels of high school students in Uskudar?

3. Do the subjective well-being levels and the moral maturity levels of high school students in Uskudar differentiate into age, gender, school type, class level, place the student has lived mostly, educational level of mother, educational level of father, income status of student's family, survival of mother, survival of father?

4. Is there any relationship between subjective well-being and moral maturity levels of high school students in Uskudar?

\section{Method}

This research was designed as relational survey model. It was used comparisonal screening model in this research at which subjective well-being and moral maturity levels of students studying at public high schools in Uskudar.

Research sample was composed of high schools in Uskudar, Istanbul. The selection of schools and students was done by disproportionate random cluster sampling method. It was reached the $9^{\text {th }}$ and $12^{\text {nd }}$ grade students from 10 schools among 29 high schools in Uskudar. Data was collected from 459 students, and 442 of them were analyzed. In this research, Personal Information Form developed by researcher, "Subjective Well Being Scale" and "Moral Maturity Scale" were used. 
Kruskal Wallis-H test, independent $\mathrm{t}$ test, ANOVA, Mann Whitney U test, and Pearson moment correlation coefficient were used to analyze the data. The data was analyzed by SPSS for Windows 17.0 statistics program, and submitted by tables.

\section{Results}

As a result of analyses it was revealed that there was no significant difference in subjective well-being level according to age, gender, school type, class level, place the student has lived mostly, educational level of father, income status of student's family, survival of mother, survival of father. In addition to this, the difference was significant according to educational level of mother. Points the students gained from Moral Maturity Scale didn't differentiate according to age, school type, place the student has lived mostly, educational level of father, income status of student's family, survival of mother, survival of father. By the way, there were significant differences in moral maturity level according to gender, class level, income statute of student's family, and educational level of mother. There was also positive relationship between high school students' subjective well-being and moral maturity level.

\section{Discussion}

Individuals who participated the study to have similar developmental characteristics may lead subjective well-being levels not differintiate according to age. Subjective well-being levels of students did not differentiate acoording to gender at this research. This result adjusted to other studies about this point (Akgündüz ve Bardakoğlu, 
2012; Aypay and Eryılmaz, 2011; Çelik, 2008; Long, Huebner, Wedell and Hills, 2012; Özen, 2005; Rees, Goswami and Bradshaw, 2010; Uçan, 2013). Similarly, there is no difference between students' subjective well-being levels studying at various types of schools. This may be caused from the school perception of students or schools to have similar features. This result may be one of the affects The Law on Unification of Education. Subjective well-being levels of students did not differentiate according to educational level of mothers/ fathers. This result contrasts with the knowledge that parent' educational level affect mental health of the children.

Moral maturity levels of students differentiated according to gender at the study. Female students' moral maturity levels were higher than the males'. This result may be explained by cultural affects. According to Turkish culture, it's seen that girls are grown more naive, motherly, and compassionate than the boys. The reason of moral maturity levels of students not to differentiate according to age may be students' similar developmental features. When moral maturity levels differientiated according to age, it differentiated according to class levels of students. $9^{\text {th }}$ grade students' moral maturity level was higher than $12^{\text {th }}$ grade students'. This result may indicate that formal education system has a negative affect on moral maturity level of students. As in the case with the subjective well-being difference according to school type, moral maturity levels of students had also no difference between students studying at different types of school. Students' moral maturity levels did not differentiate according to income status of students. This may be caused from a collapse of range of all income status levels. 
Fathers' educational level differentiated moral maturity levels of students. Students of fathers well-educated have lower moral maturity level than students of the others. It makes think about Turkish education system that change and become more competitive everyday.

Results of the study showed that there was a relationship between moral maturity and subjective well-being levels of students. In a similar way, Yûsuf Has Hacib also indicated that just a moral person could find felicity (Özden, 2007). Fârâbi also stated that happiness is one of the central terms of moral (Topdemir, 2010).

\section{Conclusion}

At this study, subjective well-being and moral maturity levels of high school students were examined in terms of different views. Results revealed some significant findings. In addition to this, if this research's sample got bigger, it could give more comprehensive results. For example, if this investigation includes more diverse schools, it would give more accurate results about Turkish education system. Therefore, it's offered that the study conducted between 2012-2013 school year can be repeated by a study of a large study in the coming years.

According to the results of study, moral maturity levels of high school students decreased with increasing class level. This result is suggested that there can be a significant point to take precautions for Turkish education system.

Another striking result is that moral maturity levels of high- 
school students decreased with increasing fathers' educational level. In this regard, it shows that formal education may not be affective on moral maturity of children. For this reason, it should be given importance to parental education.

\section{Giriş}

Huzurlu bir toplumun var olabilmesi için o toplumu meydana getiren bireylerin ahlâkî gelişimlerine önem verilmesi gerekir (Turiel, 2002). Zira ancak ruh sağlığı iyi ve ahlâklı bireyler, saadet içinde yaşayan bir toplumu oluşturabilir. Her toplumun da kendine has ahlâkî değerler sistemi vardır ve bu değerlerin muhafaza edilmesi son derece mühimdir.

Toplumda huzur, güvenlik ve istikrarın sağlanmasında millî ahlâk değerlerinin nesiller boyunca aktarılması oldukça önemlidir. $\mathrm{Bu}$ sayede birey, hem kendinden öncekilerle olan birliği korumuş olur, hem de bütün insanlar ortak bir sisteme sâhip olduğu için, kendi çağdaşlarıyla bir arada rahat yaşama imkânına kavuşur (Güngör, 1997; s.21). Burada zaman bağlaması (time binding) kavramından söz etmek yerinde olur. Zaman bağlaması, bir kuşağın, kendinden önceki kuşaklardan devraldığ kuşağa aktarmasıdır. Bu anlamda, içinde bulunulan kuşağın geliştirilmesi ve gelecek kuşaklara faydalı bir miras bırakılması hususunda her bir bireye sorumluluk düşmektedir. Gelecek bireylere bırakacağı mirası geliştirme amacına ve hassasiyetine sahip bireyler, ancak ahlâkî değerler ışığında oluşur. Köklerinin farkında olan ve fert olmayı başarmış bireyler, gelecek nesilleri de bu âidiyet duygusuyla sâhiplenerek hu- 
zurlu bir toplumun temellerini atacaktır.

Bireyin iyi bir ahlâka sahip olmasının ilk gereği, kendi eylemini doğru değerlendirebilmesidir. Bireyin herhangi bir ahlâkî ilişkisinde kendi eylemini doğru değerlendirmesi de o eyleminin (yaptığınınyapmadığının) nedenlerini kendi gözünde açığa çıkarmasına bağlıdır. Bireyin kendi eylemini değerlendirmesinin ikinci adımı, o eylemin değerini belirlemesidir. Bu ilişkideki değerlendirmenin üçüncü adımı ise, ahlâkî ilişkideki değerlendirmenin özelliğini karşılayan bireyin, kendine hesap vermesidir. Bu, aynı zamanda kişiye, dolaylı olarak ana amaçlarının bilgisini edinmesini sağlar. Kişi, kendi eylemlerini kendisine hesap verme doğrultusunda gerçekleştirdiğinde, sorumluluk denen insanî bilinçle şekillenmiş bir ortam doğar (Gündüz, 2010).

Kişinin kendisini nasıl gördüğü; kendisine ilişkin yaşantılarına, tutumuna, muamelesine ve kendisini değerlendirmesine bağlıdır. Kişinin kendisiyle olan ahlâkî ilişkisi, kendisine ilişkin değerlilik anlayışı ve ana amaçlarının oluşturduğu ilişkidir. Yine de kişinin bu kendisiyle ilişkisinin, başkalarıyla girdiği ahlâkî ilişkilerle iç içe oluştuğu gözden kaçırılmamalıdır. Bütün bunlarla birlikte, ahlâkî ilişkilerin ördüğü yapıların az çok farklı ahlâk tiplerini de ortaya çıkardığ 1 bilinmektedir (Gündüz, 2010). Bireyin huzur ve saadet içinde yaşaması ise, ancak toplumdaki bütün bireylerin sorumluluklarını insanî bir bilinçle yerine getirmesine ve erdemli davranışlar sergilemesine bağlıdır.

Tarih boyunca filozoflar ve bilim insanları, ahlâk ile mutluluk arasındaki ilişkiyi incelemişlerdir. Pozitif psikoloji akımıyla birlikte, bugünkü bilim dünyasında, mutluluğun yanında bireyin iyi oluşu, pek 
çok kavramla ele alınmaktadır. Bu kavramlardan biri de öznel iyi oluştur. Öznel iyi oluş, bilişsel ve duyuşsal olmak üzere iki temel boyuttan meydana gelmektedir. Hayat doyumunu içine alan bilişsel boyut ile pozitif duygulanım ve negatif duygulanım kavramlarını kapsayan duyuşsal boyut, öznel iyi oluşu açıklamaktadır. Öznel iyi oluş, "başkalarının belli kriterlerle kişiyi değerlendirmesi değil, kişinin bizzat kendi hayatını çeşitli yönlerden değerlendirmesi durumu" şeklinde tanımlanabilir.

Yûsuf Has Hacib, Kutadgu Bilig’te, “İyi insanın, faziletli insanın saadete ereceğini kabul etmeliyiz. Çünkü saadet, bir nevi insanın iç huzurunun dış âleme yansımasıdır." ifadesini kullanmıştır (Özden, 2007). "İyi insan, faziletli insan” olarak tanımlanan güzel ahlâklı ve ruh sağlığ 1 yerinde bireyi yetiştirmek de huzur ve saadet içinde yaşayan bir toplumun kurulması açısından önemlidir.

Bir bireyin ruh sağlığının iyi olmasının kaynakları, anne karnına düşmeden önce başlar. Anne ve baba adayının aldığı terbiye, genetik özellikleri ve çevresel şartlar, çocuğun ruh sağlığı açısından önemli özelliklerdir. Dünyaya geldikten sonra ise aile ve mürebbiyelerinin özenli eğitimine ihtiyaç duyan birey, delikanlılık çağında da yetiştiricilerinin dikkat ve anlayışıyla iyi bir ahlâka sahip olabilir.

\section{Öznel İyi Oluş}

İyi oluş değişkenine ilişkin alanyazın incelendiğinde, kavramın çok farklı yapılarla ve isimlerle ele alındığı görülmektedir. Bu isimler arasında iyi oluş, öznel iyi oluş, mutluluk, psikolojik iyi oluş, duygusal iyi oluş, hayat kalitesi, kişisel iyi oluş yer almaktadır. Bu kavramlar 
arasında iyi olma hâlinin boyutları ile açıklamalarında farklılıklar görülmekle birlikte, aynı tanım için farklı terimlerin kullanıldığı da gözden kaçmamaktadır (Türkmen, 2012).

Öznel iyi oluş kavramı, bireyin bilişsel ve duyuşsal olarak kendisini değerlendirmesi durumudur. Öznel iyi oluş kavramının temelde bilişsel ve duyuşsal olmak üzere iki boyutu vardır. Hayat doyumunu içine alan bilişsel boyut ile pozitif duygulanım ve negatif duygulanım kavramlarını kapsayan duyuşsal boyut, öznel iyi oluşu açılar.

Birçok araştırmada, öznel iyi oluş ile mutluluk kavramlarının eş anlamlı olarak kullanıldığg görülmektedir (Balc1, 2011; Hamurcu, 2011). Ancak, İngilizcede mutluluk kelimesinin farklı anlamlar (neş’e, sevinç, memnuniyet vb.) içermesi sebebiyle pek çok bilim adamı tarafından mutluluk yerine daha spesifik bir kavram olan öznel iyi oluş (subjective well-being) kavramı tercih edilmektedir (Diener, 2006).

$\mathrm{Bu}$ araştırmada ele alınan öznel iyi oluş kavramı, bireyin şimdiki ve geçmiş hayat dönemlerini nasıl değerlendirdiğinin bilimsel analizini kapsayan bir alanı tanımlamaktadır. $\mathrm{Bu}$ değerlendirmeler, insanın duygusal tepkilerinden davranışlarına, duygusal durumlarından hayat doyumları konusundaki yargılamaları ile evlilik ve iş doyumuna kadar birçok kavramı kapsar. Kısaca öznel iyi oluş, "bireyin perspektifinden iyi olma hâli” olarak ele alınır (Lucas ve Diener, 1999).

\section{Ahlâkî Olgunluk}

Ahlâk kelimesi, Arapça "hulk" kelimesinin çoğulu olup Türkçede yaygın bir yanlışlıkla tekil olarak kullanılır. Hulk; din, tabiat, huy ve karakter gibi manalara gelir (Kılıç, 2007; Gündüz, 2010). Batı litera- 
türüne bakıldığında, "ahlâk" kelimesine karşılık, "moral” kelimesi karşımıza çıkmaktadır. "Moral" kelimesi, Latince "moralis" âdet, karakter, hâl ve hareket tarzı demektir. Longman (1995) sözlügüünde, "moral” kavramı, iyi ile kötü arasındaki fark; doğru ve yanlış davranışın ne olduğuyla ilgili ilkeler bütünü ve doğru ile yanlış arasındaki farkı anlayabilme yeteneği olarak tanımlanmıştır. İslâm düşüncesinde ahlâk ise, öncelikle bir yeti ve meleke olarak yer almıştır. Bu anlamda Gazâlî kelimenin anlamını; "Ahlâk, nefiste yerleşmiş bulunan bir melekedir (yetidir) ki ondan, fikrî bir zorlamaya lüzûm kalmaksızın fiiller kolayca ortaya çıkar.” şeklinde yapar (akt; Kılıç, 2007). İbn-i Sinâ, ahlâkı, dinî kaynaklı olmakla birlikte, ruhî ve manevî bir meleke olarak tarif etmiştir. Aristo anlayışını yansıtan bir tarife göre ahlâk, insan nefsinden, düşünüp taşınmaya gerek kalmaksızın, birtakım fiillerin doğmasını sağlayan melekedir (Çağrıcı, 1989).

Kutadgu Bilig’te de birçok ahlâkî kavram bulunmaktadır. Yûsuf Has Hacib'e göre, bireyin kendine karşı başlıca ödevi, bilgi edinmektir. Ayrıca bu eserde, ahlâkî açıdan olumlu kavramlar arasında; bilgili olmak (biliglik), saadet-mutluluk (kutluluk), doğruluk-adalet (könilik), fazilet (erdem), iyi-iyilik (edgü), faydalılık (asıglı), anlayışlı olmak (ukuşluk), sevgi-sadakât-vefa, alçakgönüllülük, cömertlik (akı), yiğitlik (alplık), merhamet-şefkat-sadakât (bağırsak), sabırlı olmak (serinli) ve hayâ (avut) sıralanmıştır. Ahlâkî açıdan olumsuz kavramlardan ise, yalan-yalancılık (yalgan), acelecilik, bilgisizlik, kibirli olmak, cimrilik-hasislik (saranlık) ile açgözlülük yer almaktadır (Özden, 2007). Kaşgarlı Mahmut (1985) ise, ahlâk meselesinde, "güzellik, sevimlilik, tatlılık, edep, büyükleri ağırlama, yiğitlik ve mertlik" maddelerini s1- 
ralar.

Ahlâk, bireyin kendi dışındaki bütün varlıklarla olan ilişkilerini düzenlemek için konmuş kaidelerin bir bütünüdür. Biz, bir insanın davranışlarına bakarak, onlardan genel bir hüküm çıkarıyoruz ve o insan hakkında çıkardığımız bu genel hükme "şahsiyet" diyoruz. Şahsiyet, büyük ölçüde ahlâkî davranışlardan oluşan insanî bir özelliktir (Güngör, 1997). Dürüstlük, mertlik, konukseverlik, haysiyet sahibi olmak gibi iyi ahlâk vasıfları, aynı zamanda iyi şahsiyet vasıfları olarak bilinir (Güngör, 1997, s.18).

Ahlâkî olgunluk, "ahlâkî tutumlar bakımından yetkin ve zirvede olma durumu ve bu duruma en zengin, en gerekli ve en dolgun anlamını veren ahlâkî niteliklerin toplamını" ifade eder. Ahlâkî olgunluk kavramı, ahlâkî gelişim kavramından faydalanılarak açıklanabilir. Birey, öğrenmeleri ve çeşitli etmenler vasıtasıyla geliştikçe, onun olgunlaşmas1 da beklenir. Lickona (1991)'a göre ahlâkî olgunluğa sâhip bir bireyin özellikleri incelendiğinde, güvenilir, sorumlu, saygılı, âdil, kendini kontrol edebilen, empati yeteneği gelişmiş iyi bir insan ve bütün bunların ötesinde kanunlara ve kurallara uyan iyi bir vatandaşla karşılaşılmaktadır (akt; Şengün ve Kaya, 2007; Özden, 2007).

\section{Yöntem}

\section{Araştırmanın Amacı}

Yapılan araştırmalara göre, çocuklar 12-14 yaşından sonra artık büyük insanların mantıklı düşünce sistemini kullanabilecek derecede gelişmiş bir zekâya sâhip bulunmaktadırlar (Güngör, 1997, s.51). Küçük yaşlarından itibaren ahlâkî davranışı gerek sözlü öğretiler, gerekse 
davranışsal modeller aracılığıyla öğrenmeye çalışan bireyin, bu yaşından itibaren davranışlarını gözden geçirip değerlendirmeye başlaması gerekçesiyle bu araştırmada çalışma grubu, 14-20 yaşları arasındaki bireylerden oluşturulmuştur. Üsküdar ilçesindeki liselerde öğrenimlerine devam eden öğrencilerin öznel iyi oluşları ile ahlâkî olgunluk seviyeleri, çeşitli değişkenlere göre incelenerek "Üsküdar'da öğrenim gören lise öğrencilerinin öznel iyi oluş ile ahlâkî olgunluk seviyeleri arasında ilişki var mıdır?" problemine cevap aranmıştır. Araştırmanın alt problemleri şu şekilde kurgulanmıştır:

İstanbul'un Üsküdar ilçesinde öğrenim gören lise öğrencilerinin;

1. Öznel iyi oluş seviyeleri nasıldır?

2. Ahlâkî olgunluk seviyeleri nasıldır?

3. Öznel iyi oluş ve ahlâkî olgunluk seviyeleri; yaş, cinsiyet, okul türü, sınıf seviyesi, gelir seviyesi, anne eğitim seviyesi, baba eğitim seviyesi, annenin hayatta olup olmama durumu ve babanın hayatta olup olmama durumu değişkenlerine göre farklılaşmakta midir?

4. Öznel iyi oluş ve ahlâkî olgunluk seviyeleri arasında anlamlı bir ilişki var mıdır?

\section{Araştırmanın Modeli}

$\mathrm{Bu}$ araştırma, ilişkisel tarama yöntemiyle oluşturulmuş betimsel bir çalışmadır. Üsküdar'da resmî ortaöğretim okullarında öğrenim görmekte olan lise öğrencilerinin, öznel iyi oluş ve ahlâkî olgunluk seviyeleri arasındaki ilişkinin karşılaştırılması için yapılan çalışmada, ilişkisel tarama modellerinden karşılaştırma türü tarama modeli kulla- 
nılmıştır.

\section{Evren ve Örneklem}

Araştırmanın evrenini, 2012-2013 eğitim öğretim y1lında İstanbul ili Üsküdar ilçesinde öğrenim görmekte olan ortaöğretim öğrencileri oluşturmaktadır. Örneklem, Üsküdar ilçesinde öğrenim görmekte olan öğrenciler arasından tesadüfî oransız küme örnekleme yöntemiyle belirlenmiştir. Örneklem belirlenirken öncelikle, Üsküdar ilçesinde hizmet veren devlet liseleri listelenmiştir. Daha sonra her bir lisenin ismi kâğıtlara yazılarak bir torbaya atılmış, toplam 29 okul arasından 10 okul belirlenmiştir. Belirlenen okulların 9. ve 12. sınıf öğrencilerine ulaşılmış, toplam 459 öğrenciden veri toplanmıştır. Yapılan ayıklama işleminden sonra bunlardan 442'si işleme tâbi tutulmuştur.

\section{Veri Toplama Araçları}

Araştırmada, kişisel bilgi formu, “Öznel İyi Oluş Ölçeği-Lise Formu” ve “Ahlâkî Olgunluk Ölçeği” kullanılmıştır.

Kişisel Bilgi Formu: Araştırmacı tarafından hazırlanan bu formda öğrencilerin yaşlarını, cinsiyetini, eğitim gördükleri okulu, okudukları sınıfı, hayatlarının çoğunu geçirdikleri yeri, âilenin gelir seviyesini, anne eğitim durumunu, baba eğitim durumunu ve anne-babanın hayatta olup olmama durumunu belirlemeye yönelik sorular yer almaktadir.

Öznel İyi Oluş Ölçeği-Lise Formu: 2004 y1lında Tuzgöl-Dost tarafından yetişkin formu geliştirilen Öznel İyi Oluş Ölçeği’nin lise formu için geçerlik ve güvenirlik çalışmaları, Özen tarafından 2005 yılında 
gerçekleştirilmiştir. Ölçeğin lise öğrencileriyle kullanılıp kullanılmayacağını belirlemek amacıyla yapılan çalışmalarda, ölçüt geçerliği için, Reynolds Ergen Depresyon Ölçeği (REDÖ) kullanılmıştır. Araştırmacı tarafından ölçüt geçerliğini sınamak için Öznel İyi Oluş Ölçeği ile Reynolds Ergen Depresyon Envanteri, 45 kişilik bir gruba bir gün arayla uygulanmış ve grup üyelerinin her iki ölçekten aldığı puanlar arasındaki korelasyon, Spearman'ın rho katsayısı hesaplanarak bulunmuştur. Her iki ölçekten alınan puanlar arasında -.60 değerinde negatif yönlü bir ilişki bulunmuştur $(p<.01)$. Ölçeğin güvenilirliği, biri test tekrar test diğeri iç tutarlılık olmak üzere iki yolla hesaplanmıştır. Ölçeğin araştırma örnekleminde yer alan 74 kişilik bir gruba iki hafta ara ile iki kez uygulanması sonucu elde edilen test tekrar test güvenilirlik katsayıs1 .82 olarak hesaplanmıştır. Ölçeğin 196 kişilik bir gruba yapılan uygulama sonuçlarına göre hesaplanan Cronbach Alfa katsayısı ise .91 'dir. Bu sonuçlara göre ölçeğin ergenler için güvenilir bir ölçek olduğu ileri sürülebilir. Öznel İyi Oluş Ölçeği (LF) 37 maddeden oluşmaktadır. Kişinin hayat doyumunu etkileyen alanlara iliş̧in kişisel yargılar ile olumlu ve olumsuz duygu ifadelerinden oluşmaktadır. Ölçekten alınabilecek en yüksek puan 185, en düşük puan ise 37'dir (Özen, 2005).

Ahlâkî Olgunluk Ölçeği: 66 maddeden oluşan beşli likert tipi bir ölçek olup, bireylerin ahlâkî olgunluk seviyelerini ölçmeyi amaçlamaktadır. Ahlâkî Olgunluk Ölçeğinin geçerlik ve güvenirlikle ilgili verileri, Samsun ili merkez liselerinden Mayıs-2007 ayında tesadüfî olarak seçilen 830 öğrenciden elde edilmiştir. Ahlâkî Olgunluk Ölçeğinin geçerliğini belirlemek için, önce uzman görüşleri alınmıştır. Ölçeğin 
yap1 geçerliği için faktör analizi yapılmış ve maddelerin faktör yüklerinin birinci faktörde toplandı̆̆ı görülmüştür. Ayrıca madde analizi sonucu, madde-toplam puan korelasyon katsayıları ( $\mathrm{p}<0.01)$ seviyesinde önemli görülmüştür. Ölçeğin ölçüt geçerliğine, Değerlerin Belirlenmesi Testi (DIT) ile bakılmıştır. DIT’ın gelenek ötesi seviye puanı (P) ile Ahlâkî Olgunluk Ölçeği puanları arasındaki korelasyon katsayısı $0.21(p<.05)$ seviyesinde önemli bulunmuştur. Ahlâkî Olgunluk Ölçeğinin güvenirliği için, test-tekrar test, test-yarı test ve Cronbach Alfa güvenirlik kontrol yöntemleri kullanılmıştır. Ölçeğin, test-tekrar test güvenirlik katsayısı 0.88 olarak, test-yarı test güvenirlik katsayıs1 0.89 olarak, Cronbach Alfa güvenirlik katsayısı ise 0.93 olarak bulunmuştur. Bu sonuçlara göre, “Ahlâkî Olgunluk Ölçeği”nin geçerli ve güvenilir olduğu kanısına varılmıştır. Ahlâkî Olgunluk Ölçeğinden alınabilecek en yüksek puan $(66 \times 5=330)$, en düşük puan ise (66x1=66)'dır. Yüksek puan, yüksek ahlâkî olgunluk seviyesi; düşük puan ise düşük ahlâkî olgunluk seviyesinin göstergesi olmaktadır (Şengün ve Kaya, 2007).

\section{Verilerin Toplanması}

Araştırmada kullanılan bilgi toplama araçları, 2012-2013 eğitim-öğretim yılı bahar döneminde uygulanmıştır. Millî Eğitim Bakanlığg'ndan gerekli izinler alındıktan sonra uygulama yapılacak okullara uygulama hakkında bilgi verilmiştir. Uygulama yapılabilecek derslerin gün ve saatleri öğrenilmiştir. Belirlenen gün ve saatte öğrencilere Ahlâkî Olgunluk Ölçeği, Öznel İyi Oluş Ölçeği ve Kişisel Bilgi Formu bir oturumda uygulanmıştır. Uygulama araştırmacı tarafından yapılmış 
ve derslere girip uygulama yapma konusunda, okul idaresinden, okul psikolojik danışma ve rehberlik servisinden ve branş öğretmenlerinden yardım alınmıştır. Araştırmacı tarafindan uygulama yapılan sınıflarda, araştırma ve araştırmacı hakkında gerekli bilgiler verilmiştir. KBF'nu doğru ve eksiksiz doldurulmalarının, ölçekteki maddelerin tamamına özenle cevap vermelerinin gerekli olduğu bildirilmiştir. Verecekleri cevapların içten ve doğru olmasının araştırma sonuçları için önemi vurgulanmıştır. Ayrıca verilen bilgilerin gizliliğine özen gösterileceği de belirtilmiştir. Uygulama, ortalama 45 dakika sürmüştür. On okulda uygulamaların tamamlanması yaklaşık 2 haftalık bir süreyi kapsamıştır.

\section{Verilerin Analizi}

İstatistiksel çözümlemelere geçmeden önce, demografik değişkenler gruplandırılmış, ardından öğrencilere uygulanan ölçekler (Öznel İyi Oluş Ölçeği-Lise Formu ve Ahlâkî Olgunluk Ölçeği) puanlanmıştır. Daha sonra elde edilen verilerin istatistiksel çözümlemeleri bilgisayar ortamında gerçekleştirilmiştir. $\mathrm{Bu}$ merhalede gruplar içerisinde normal dağılım özelliği göstermeyen $(\mathrm{N}<30)$ gruplar için non-parametrik teknikler, normal dağılım özelliği gösteren dağılımlar içinse parametrik analiz teknikleri kullanılmıştır.

\section{Bulgular}

$\mathrm{Bu}$ bölümde, öncelikli olarak araştırmaya katılan öğrencilerin demografik bilgilerine ilişkin veriler sunulduktan sonra, araştırma sorularına yanıt aramak için gerçekleştirilen analizlerden elde edilen bulgulara yer verilmiştir. 
Tablo 1. Öznel İyi Oluş Ölçeği Puanlarının Yaş Değişkenine Göre Farklılaşıp Farklılaşmadığını Belirlemek Üzere Yapılan Kruskal Wallis-H Testi Sonuçları

\begin{tabular}{ccccccc}
\hline Puan & Gruplar & $N$ & $\bar{x}_{\text {sira }}$ & $\boldsymbol{x}^{\mathbf{2}}$ & $s d$ & $p$ \\
\hline \multirow{3}{*}{ Öznel } & 14 & 15 & 219.10 & & & \\
İyi & 15 & 190 & 232.33 & & & \\
Oluş & 16 & 23 & 208.07 & & & \\
& 17 & 44 & 217.31 & 9.00 & 5 & .109 \\
& 18 & 139 & 198.89 & & & \\
& 19 & 29 & 261.97 & & & \\
& Toplam & 440 & & & & \\
\hline
\end{tabular}

Tabloda görüldüğü üzere, örneklemi oluşturan öğrencilerin Öznel İyi Oluş Ölçeği puanlarının yaş değişkenine göre anlamlı bir farklılık gösterip göstermediğini belirlemek amacıyla gerçekleştirilen Kruskal Wallis-H testi sonucunda grupların aritmetik ortalamaları arasındaki fark istatistiksel olarak anlamlı bulunmamıştır $\left(x^{2}=9.00\right.$; $\mathrm{sd}=5)$.

Tablo 2. Ahlâkî Olgunluk Ölçeği Puanlarının Yaş Değişkenine Göre Farklılaşıp Farklılaşmadığını Belirlemek Üzere Yapılan Kruskal Wallis- H Testi Sonuçları

\begin{tabular}{ccccccc}
\hline Puan & Gruplar & $\mathbf{N}$ & $\bar{x}_{\text {sira }}$ & $\boldsymbol{x}^{\mathbf{2}}$ & sd & $p$ \\
\hline \multirow{4}{*}{ Ahlâkî } & 14 & 15 & 206.63 & & & \\
Olgunluk & 15 & 190 & 234.96 & 5.89 & 5 & .317 \\
& 16 & 23 & 230.70 & & & \\
& 17 & 44 & 216.85 & & & \\
& 18 & 139 & 201.61 & & & \\
& 19 & 29 & 220.95 & & & \\
\hline
\end{tabular}


Tabloda görüldüğü üzere, örneklemi oluşturan öğrencilerin Ahlâkî Olgunluk Ölçeği puanlarının yaş değişkenine göre anlamlı bir farklılık gösterip göstermediğini belirlemek amacıyla gerçekleştirilen Kruskal Wallis-H testi sonucunda grupların aritmetik ortalamaları arasındaki fark istatistiksel olarak anlamlı bulunmamıştır $\left(x^{2}=5.89\right.$; $\mathrm{sd}=5)$.

Tablo 3. Öznel İyi Oluş Ölçeği Puanlarının Öğrencinin Cinsiyeti Değişkenine Göre Farklılaşıp Farklılaşmadığını Belirlemek Üzere Yapılan Bağımsız Grup t Testi Sonuçları

\begin{tabular}{ccccccccc}
\hline \multirow{2}{*}{ Puan } & \multirow{2}{*}{ Gruplar } & \multirow{2}{*}{$\mathbf{N}$} & $\overline{\boldsymbol{X}}$ & ss & $\mathrm{Sh}_{\overline{\mathrm{x}}}$ & \multicolumn{3}{c}{$\boldsymbol{t}$ Testi } \\
\hline Öznel & Erkek & 178 & 140.79 & 19.36 & 1.45 & $\boldsymbol{s} \boldsymbol{p}$ & $\boldsymbol{p}$ \\
İyi Oluş & $\mathrm{K} 1 \mathrm{z}$ & 257 & 143.63 & 20.66 & 1.29 & & & \\
\hline
\end{tabular}

Tabloda görüldüğü gibi, örneklemi oluşturan öğrencilerin Öznel İyi Oluş Ölçeği puanlarının öğrencinin cinsiyeti değişkenine göre anlamlı bir farklılık gösterip göstermediğini belirlemek amacıyla gerçekleştirilen bağımsız grup t testi sonucunda, grupların aritmetik ortalamaları arasındaki fark istatistiksel olarak anlamlı bulunmamıştır $(t=-1,45 ; p>.05)$.

Tablo 4. Ahlâkî Olgunluk Ölçeği Puanlarının Öğrencinin Cinsiyeti Değişkenine Göre Farklılaşıp Farklılaşmadığını Belirlemek Üzere Yapılan Bağımsiz Grup t Testi Sonuçları

\begin{tabular}{|c|c|c|c|c|c|c|c|c|}
\hline \multirow{2}{*}{ Puan } & \multirow{2}{*}{ Gruplar } & \multirow{2}{*}{$\mathbf{N}$} & \multirow{2}{*}{$\bar{X}$} & \multirow{2}{*}{ ss } & \multirow{2}{*}{$\mathrm{Sh}_{\overline{\mathrm{x}}}$} & \multicolumn{3}{|c|}{$t$ Testi } \\
\hline & & & & & & $t$ & $S d$ & $p$ \\
\hline Ahlâkî & Erkek & 178 & 252.96 & 34.64 & 2.60 & -55 & & 000 \\
\hline Olgunluk & $\mathrm{K}_{1 \mathrm{Z}}$ & 257 & 269.46 & 27.12 & 1.70 & 0.56 & 433 & .000 \\
\hline
\end{tabular}


Tabloda görüldüğü gibi, örneklemi oluşturan öğrencilerin Ahlâkî Olgunluk Ölçeği puanlarının öğrencinin cinsiyeti değişkenine göre anlamlı bir farklılık gösterip göstermediğini belirlemek amacıyla gerçekleştirilen bağımsız grup $\mathrm{t}$ testi sonucunda, grupların aritmetik ortalamaları arasındaki fark istatistiksel olarak anlamlı bulunmuştur $(t=-5.56 ; p<.001)$. Söz konusu farkl111k k1z öğrencilerin lehine gerçekleşmiştir.

Tablo 5. Öznel İyi Oluş Ölçeği Puanlarının Okul Türü Değişkenine Göre Farklılaşıp Farklılaşmadığını Belirlemek Üzere Yapılan Tek Yönlü Varyans Analizi (ANOVA) Sonuçları

\begin{tabular}{|c|c|c|c|c|c|c|c|c|c|c|}
\hline \multirow[b]{2}{*}{ Puan } & \multirow{2}{*}{$\frac{f, \overline{\mathrm{x}} \text { ve }}{\text { Gruplar }}$} & \multirow{2}{*}{$\begin{array}{c}S S \\
N\end{array}$} & \multicolumn{2}{|c|}{ Değerleri } & \multicolumn{6}{|c|}{ ANOVA Sonuçları } \\
\hline & & & $\overline{\mathrm{X}}$ & $S S$ & Var. K. & $K T$ & $S d$ & $K O$ & $F$ & $p$ \\
\hline \multirow{5}{*}{$\begin{array}{c}\text { Öznel } \\
\text { İyi } \\
\text { Oluş }\end{array}$} & SML $^{*}$ & 132 & 142.05 & 22.25 & G.Arası & 2642.15 & 3 & 880.72 & & \\
\hline & $\mathrm{AL}^{* *}$ & 178 & 144.19 & 18.81 & G.İçi & 175952.13 & 438 & 401.72 & & \\
\hline & $\mathrm{TeML}^{* * *}$ & 84 & 143.46 & 19.22 & Toplam & 178594.27 & 441 & & 2.19 & .088 \\
\hline & $\operatorname{TiML}^{* * * *}$ & 48 & 136.00 & 19.46 & & & & & & \\
\hline & Toplam & 442 & 142.52 & 20.12 & & & & & & \\
\hline
\end{tabular}

Tabloda görüldüğü üzere, örneklemi oluşturan öğrencilerin Öznel İyi Oluş Ölçeği puanlarının okul türü değişkenine göre anlamlı bir farklılık gösterip göstermediğini belirlemek amacıyla gerçekleştirilen tek yönlü varyans analizi (ANOVA) sonucunda grupların aritmetik ortalamaları arasındaki fark istatistiksel olarak anlamlı bulunmamıştır $(F=2.19 ; p>.05)$.

Tablo 6. Ahlâkî Olgunluk Ölçeği Puanlarının Okul Türü Değişkenine Göre Farklılaşıp Farklılaşmadığını Belirlemek Üzere Yapılan Tek Yönlü Varyans Analizi (ANOVA) Sonuçları 


\begin{tabular}{|c|c|c|c|c|c|c|c|c|c|c|}
\hline & $f, \overline{\mathrm{x}} \mathbf{v e}$ & $S S$ & Değerle & & & ANO & VA S & onuçları & & \\
\hline Puan & Gruplar & $\mathbf{N}$ & $\overline{\mathrm{X}}$ & $s S$ & Var. $K$ & $K T$ & $S d$ & KO & $F$ & $p$ \\
\hline \multirow{5}{*}{$\begin{array}{l}\text { Ahlâkî } \\
\text { Olgunluk }\end{array}$} & $\mathrm{SML}^{*}$ & 132 & 266.70 & 28.78 & G.Aras! & 5871.27 & 3 & 1957.09 & & \multirow{5}{*}{.111} \\
\hline & $\mathrm{AL}^{* *}$ & 178 & 262.18 & 29.08 & G.İci & 425155.59 & 438 & 970.68 & 2.02 & \\
\hline & $\mathrm{TeML}^{* * *}$ & 84 & 263.15 & 33.40 & Toplam & 431026.86 & 441 & & & \\
\hline & $\mathrm{TiML}^{* * * *}$ & 48 & 253.92 & 39.76 & & & & & & \\
\hline & Toplam & 442 & 262.82 & 31.26 & & & & & & \\
\hline
\end{tabular}

Tabloda görüldüğü üzere, örneklemi oluşturan öğrencilerin Ahlâkî Olgunluk Ölçeği puanlarının okul türü değişkenine göre anlamlı bir farklılık gösterip göstermediğini belirlemek amacıyla gerçekleștirilen tek yönlü varyans analizi (ANOVA) sonucunda grupların aritmetik ortalamaları arasındaki fark istatistiksel olarak anlamlı bulunmamıştır $(F=2.02 ; p>.05)$.

Tablo 7. Öznel İyi Oluş Ölçeği Puanlarının Öğrencinin Sınıf Seviyesi Değişkenine Göre Farklılaşıp Farklılaşmadığını Belirlemek Üzere Yapılan Bağımsız Grup t Testi Sonuçları

\begin{tabular}{|c|c|c|c|c|c|c|c|c|}
\hline \multirow{2}{*}{ Puan } & \multirow{2}{*}{ Gruplar } & \multirow{2}{*}{$\mathbf{N}$} & \multirow{2}{*}{$\bar{X}$} & \multirow{2}{*}{ SS } & \multirow{2}{*}{$\mathrm{Sh}_{\overline{\mathrm{x}}}$} & \multicolumn{3}{|c|}{$\boldsymbol{t}$ Testi } \\
\hline & & & & & & $\bar{t}$ & $S d$ & $p$ \\
\hline $\begin{array}{l}\text { Öznel } \\
\text { İyi Olus }\end{array}$ & $\begin{array}{l}\text { 9. sinif } \\
\text { 12. sinif }\end{array}$ & $\begin{array}{l}178 \\
257\end{array}$ & $\begin{array}{l}143.70 \\
141.25\end{array}$ & $\begin{array}{l}20.63 \\
19.53\end{array}$ & $\begin{array}{l}1.36 \\
1.34\end{array}$ & 1.28 & 440 & .200 \\
\hline
\end{tabular}

Tabloda görüldüğü gibi, örneklemi oluşturan öğrencilerin Öznel İyi Oluş Ölçeği puanlarının öğrencinin sınıf seviyesi değişkenine göre anlamlı bir farkl1lık gösterip göstermediğini belirlemek amacıyla gerçekleştirilen bağımsız grup t testi sonucunda, grupların aritmetik ortalamaları arasındaki fark istatistiksel olarak anlamlı bulunmamıştır $(t=1.28 ; p>.05)$. 
Tablo 8. Ahlâkî Olgunluk Ölçeği Puanlarının Öğrencinin Sınıf Seviyesi Değişkenine Göre Farklılaşıp Farklılaşmadığını Belirlemek Üzere Yapılan Bağımsız Grup t Testi Sonuçları

\begin{tabular}{llccccccc}
\hline \multirow{2}{*}{ Puan } & \multirow{2}{*}{ Gruplar } & \multirow{N}{*}{$\mathbf{N}$} & $\overline{\boldsymbol{X}}$ & Ss & $\mathrm{Sh}_{\overline{\mathrm{x}}}$ & \multicolumn{3}{c}{$\boldsymbol{t}$ Testi } \\
\hline Ahlâkî & 9. sınıf & 178 & 266.35 & 28.93 & 1.91 & \multirow{2}{*}{$\boldsymbol{S} \boldsymbol{d}$} & $\boldsymbol{p}$ \\
Olgunluk & 12. sınıf & 257 & 258.98 & 33.26 & 2.28 & & \multirow{2}{*}{40} & \multirow{2}{*}{013} \\
\hline
\end{tabular}

Tabloda görüldüğü gibi, örneklemi oluşturan öğrencilerin Ahlâkî Olgunluk Ölçeği puanlarının öğrencinin sınıf seviyesi değişkenine göre anlamlı bir farklılık gösterip göstermediğini belirlemek amacıyla gerçekleştirilen bağımsız grup t testi sonucunda, grupların aritmetik ortalamaları arasındaki fark istatistiksel olarak anlamlı bulunmuştur $(t=2.49 ; p<.05)$. Söz konusu farklılık 9. sınıf öğrencilerinin lehine gerçekleşmiştir.

Tablo 9. Öznel İyi Oluş Ölçeği Puanlarının Gelir Seviyesi Değişkenine Göre Farklılaşıp Farklılaşmadığını Belirlemek Üzere Yapılan Tek Yönlü Varyans Analizi (ANOVA) Sonuçları

\begin{tabular}{ccccccccccc}
\hline & $f, \overline{\mathrm{X}}$ ve & $S \boldsymbol{S}$ Değerleri & \multicolumn{7}{c}{ ANOVA Sonuçları } \\
\hline Puan & Gruplar & $\mathbf{N}$ & $\overline{\mathrm{X}}$ & $\boldsymbol{S S}$ & Var. K. & $\boldsymbol{K} \boldsymbol{T}$ & $\boldsymbol{S \boldsymbol { d }}$ & $\boldsymbol{K O} \boldsymbol{O}$ & $\boldsymbol{F}$ & $\boldsymbol{p}$ \\
\hline \multirow{2}{*}{ 751 TL-1500 TL } & 139 & 267.77 & 28.28 & G.Arası & 12189.31 & 5 & 2437.86 & \\
Öznel & 1501 TL-3000 TL & 178 & 263.44 & 31.36 & G.İçi & 418776.31 & 435 & 962.70 & & \\
İyi & 3001 TL-4500 TL & 53 & 259.26 & 32.00 & Toplam & 430965.62 & 440 & & 2.53 & \\
Oluş & 4501 TL ve üzeri & 54 & 251.44 & 32.19 & & & & & & \\
& Toplam & 424 & 262.83 & 31.30 & & & & & & \\
\hline
\end{tabular}

Tabloda görüldüğü üzere, örneklemi oluşturan öğrencilerin Öznel İyi Oluş Ölçeği puanlarının gelir seviyesi değişkenine göre anlamlı bir farklılık gösterip göstermediğini belirlemek amacıyla gerçekleştirilen tek yönlü varyans analizi (ANOVA) sonucunda grupların aritme- 
tik ortalamaları arasındaki fark istatistiksel olarak anlamlı bulunmuş$\operatorname{tur}(F=2.53 ; p<.05)$. Bu işlemin ardından ANOVA sonrası belirlenen anlamlı farklılığın hangi gruplardan kaynaklandığını belirlemek üzere tamamlayıcı post-hoc analiz tekniklerine geçilmiştir.

ANOVA sonrası hangi post-hoc çoklu karşılaştırma tekniğinin kullanılacağına karar vermek için öncelikle Levene's testi ile grup dağılımlarının varyanslarının homojen olup olmadığı hipotezi sınanmış, varyansların homojen olmadığı saptanmıştır $(L F=2.41 ; p<.05)$. Bunun üzerine varyansların homojen olmaması durumunda yaygınlıkla kullanılan Tamhane çoklu karşılaştırma tekniği tercih edilmiştir. Gerçekleştirilen Tamhane çoklu karşılaştırma analizi sonuçları aşağıda sunulmuştur.

Tablo 10. Öznel İyi Oluş Ölçeği Puanlarının Gelir Seviyesi Değişkenine Göre Hangi Alt Gruplar Arasında Farklılaştığını Belirlemek Üzere Yapılan Tek Yönlü Varyans Analizi (ANOVA) Sonrası Tamhane Testi Sonuçları

\begin{tabular}{ccccc}
\hline Gelir Seviyesi (i) & Gelir Seviyesi $(\mathbf{j})$ & $\bar{x}_{i}-\bar{x}_{j}$ & $\mathrm{Sh}_{\overline{\mathrm{x}}}$ & $p$ \\
\hline $751-1500$ & $1501-3000$ & 4.33 & 3.36 & .96 \\
& $3001-4500$ & 8.51 & 5.01 & .77 \\
& 4501 ve üzeri & 16.33 & 5.00 & .02 \\
\hline $1501-3000$ & $750-1500$ & -4.33 & 3.36 & .96 \\
& $3001-4500$ & 4.18 & 4.98 & 1.00 \\
& 4501 ve üzeri & 12.00 & 4.97 & .24 \\
\hline $3001-4500$ & $750-1500$ & -8.51 & 5.01 & .77 \\
& $1501-3000$ & -4.18 & 4.98 & 1.00 \\
& 4501 ve üzeri & 7.82 & 6.21 & .97 \\
\hline 4501 ve üzeri & $750-1500$ & -16.33 & 5.00 & .023 \\
& $1501-3000$ & -4.18 & 4.97 & .24 \\
& $3001-4500$ & -7.82 & 6.21 & .97 \\
\hline
\end{tabular}


Öznel iyi oluş puanlarının gelir seviyesi değişkenine göre hangi alt gruplar arasında farklılaştığını belirlemek üzere yapılan tek yönlü varyans analizi (ANOVA) sonrası Tamhane testi sonucunda geliri 751-1500 TL arasında olanlarla 4501 ve üzerinde olanlar arasında 751-1500 TL geliri olan grubun lehine istatistiksel olarak anlamlı bir farklılık saptanmıştır. Diğer alt boyutlar arasındaki farklılık istatistiksel olarak anlamlı bulunmamıştır ( $p>.05)$.

Tablo 11. Ahlâkî Olgunluk Ölçeği Puanlarının Gelir Seviyesi Değişkenine Göre Farklılaşıp Farklılaşmadığını Belirlemek Üzere Yapılan Tek Yönlü Varyans Analizi (ANOVA) Sonuçları

\begin{tabular}{ccccccccccc}
\hline & $f, \overline{\mathrm{X}}$ ve & $S \boldsymbol{S}$ & \multicolumn{1}{c}{ Değerleri } & \multicolumn{7}{c}{ ANOVA Sonuçları } \\
\hline Puan & Gruplar & $\mathbf{N}$ & $\overline{\mathrm{X}}$ & $\boldsymbol{S S}$ & Var. K. & $\boldsymbol{K} \boldsymbol{T}$ & $\boldsymbol{S \boldsymbol { d }}$ & $\boldsymbol{K} \boldsymbol{O}$ & $\boldsymbol{F}$ & $\boldsymbol{p}$ \\
\hline \multirow{4}{*}{ Ahlâkî } & 751 TL-1500 TL & 139 & 139.99 & 20.79 & G.Arası & 4051.24 & 5 & 810.25 & \\
Olgunluk & 3001 TL-3000 TL & 178 & 143.03 & 20.35 & G.İçi & 174512.47 & 435 & 401.18 & & \\
& 4501 TL ve üzeri & 53 & 145.51 & 18.54 & Toplam & 178563.71 & 440 & & 2.02 & \\
& 54 & 147.33 & 17.49 & & & & & & \\
& Toplam & 424 & 142.54 & 20.15 & & & & & & \\
\hline
\end{tabular}

Tabloda görüldüğü üzere, örneklemi oluşturan öğrencilerin Öznel İyi Oluş Ölçeği puanlarının gelir seviyesi değişkenine göre anlamlı bir farklılık gösterip göstermediğini belirlemek amacıyla gerçekleştirilen tek yönlü varyans analizi (ANOVA) sonucunda grupların aritmetik ortalamaları arasındaki fark istatistiksel olarak anlamlı bulunmamiştır $(F=2.02 ; p>.05)$.

Tablo 12. Öznel İyi Oluş Ölçeği Puanlarının Anne Eğitim Seviyesi Değişkenine Göre Farklılaşıp Farklılaşmadığını Belirlemek Üzere Yapılan Tek Yönlü Varyans Analizi (ANOVA) Sonuçları 


\begin{tabular}{|c|c|c|c|c|c|c|c|c|c|c|}
\hline \multicolumn{5}{|c|}{$f, \overline{\mathrm{X}}$ ve $s s$ Değerleri } & \multicolumn{6}{|c|}{ ANOVA Sonuçları } \\
\hline Puan & Gruplar & $\mathbf{N}$ & $\overline{\mathrm{X}}$ & SS & Var. K. & $K T$ & $S d$ & KO & $\boldsymbol{F}$ & $p$ \\
\hline \multirow{5}{*}{$\begin{array}{c}\text { Öznel } \\
\text { İyi } \\
\text { Oluş }\end{array}$} & İlkokul & 179 & 141.00 & 19.97 & G.Arası & 4301.41 & 5 & 860.28 & \multirow{5}{*}{2.15} & \multirow{5}{*}{.059} \\
\hline & Ortaokul & 75 & 140.36 & 20.65 & G.İçi & 173170.01 & 433 & 399.931 & & \\
\hline & Lise & 94 & 143.27 & 20.32 & Toplam & 177471.41 & 438 & & & \\
\hline & Üniversite & 75 & 147.47 & 19.06 & & & & & & \\
\hline & Toplam & 423 & 142.64 & 15.51 & & & & & & \\
\hline
\end{tabular}

Tabloda görüldüğü üzere, örneklemi oluşturan öğrencilerin Öznel İyi Oluş Ölçeği puanlarının annenin eğitim seviyesi değişkenine göre anlamlı bir farklılık gösterip göstermediğini belirlemek amacıyla gerçekleştirilen tek yönlü varyans analizi (ANOVA) sonucunda grupların aritmetik ortalamaları arasındaki fark istatistiksel olarak anlamlı bulunmamıştır $(F=2.15 ; p>.05)$.

Tablo 13. Ahlâkî Olgunluk Ölçeği Puanlarının Anne Eğitim Seviyesi Değişkenine Göre Farklılaşıp Farklılaşmadı̆̆ını Belirlemek Üzere Yapılan Tek Yönlü Varyans Analizi (ANOVA) Sonuçları

\begin{tabular}{|c|c|c|c|c|c|c|c|c|c|c|}
\hline &,$\overline{\mathrm{X}}$ ve & $S S$ & Değerler & & & ANOV & A Sor & uçları & & \\
\hline Puan & Gruplar & $N$ & $\overline{\mathrm{X}}$ & SS & Var. K. & $K T$ & $S d$ & KO & $F$ & $p$ \\
\hline & İlkokul & 179 & 266.75 & 28.24 & G.Arası & 9452.40 & 5 & 1890.48 & & \\
\hline & Ortaokul & 75 & 263.20 & 32.61 & G.İçi & 414799.70 & 433 & 957.97 & & \\
\hline $\begin{array}{l}\text { Ahlâkî } \\
\text { Olounluk }\end{array}$ & Lise & 94 & 259.15 & 35.62 & Toplam & 424252.10 & 438 & & 1.97 & 081 \\
\hline & Üniversite & 75 & 256.67 & 30.40 & & & & & & .081 \\
\hline & Toplam & 423 & 262.96 & 31.12 & & & & & & \\
\hline
\end{tabular}

Tabloda görüldüğü üzere, örneklemi oluşturan öğrencilerin Ahlâkî Olgunluk Ölçeği puanlarının annenin eğitim seviyesi değişkenine göre anlamlı bir farklılık gösterip göstermediğini belirlemek amaciyla gerçekleştirilen tek yönlü varyans analizi (ANOVA) sonucunda grupların aritmetik ortalamaları arasındaki fark istatistiksel olarak anlamlı bulunmamıştır $(F=1.97 ; p>.05)$. 
Tablo 14. Öznel İyi Oluş Ölçeği Puanlarının Baba Eğitim Seviyesi Değişkenine Göre Farklılaşıp Farklılaşmadığını Belirlemek Üzere Yapılan Kruskal Wallis-H Testi Sonuçları

\begin{tabular}{ccccccc}
\hline Puan & Gruplar & $N$ & $\bar{x}_{\text {sira }}$ & $x^{2}$ & $s d$ & $p$ \\
\hline \multirow{2}{*}{ Öznel İyi } & İlkokul & 91 & 208.70 & & & \\
Oluş & Ortaokul & 99 & 208.17 & 6.66 & 4 & .155 \\
& Lise & 123 & 212.98 & & & \\
& Üniversite & 100 & 247.34 & & & \\
& Lisansüstü & 25 & 224.42 & & & \\
& Toplam & 439 & & & & \\
\hline
\end{tabular}

Tabloda görüldüğü üzere, örneklemi oluşturan öğrencilerin Öznel İyi Oluş Ölçeği puanlarının baba eğitim seviyesi değişkenine göre anlamlı bir farklılık gösterip göstermediğini belirlemek amacıyla gerçekleştirilen Kruskal Wallis-H testi sonucunda grupların aritmetik ortalamaları arasındaki fark istatistiksel olarak anlamlı bulunmamıştır $\left(x^{2}=6.66 ; s d=4\right)$.

Tablo 15. Ahlâkî Olgunluk Ölçeği Puanlarının Baba Eğitim Seviyesi Değişkenine Göre Farklılaşıp Farklılaşmadığını Belirlemek Üzere Yapılan Kruskal Wallis-H Testi Sonuçları

\begin{tabular}{ccccccc}
\hline Puan & Gruplar & $\mathbf{N}$ & $\bar{x}_{\text {sira }}$ & $\boldsymbol{x}^{\mathbf{2}}$ & sd & $p$ \\
\hline \multirow{3}{*}{ Ahlâkî } & İlkokul & 91 & 234.55 & & & \\
Olgunluk & Ortaokul & 99 & 243.29 & 9.61 & 4 & .048 \\
& Lise & 123 & 206.45 & & & \\
& Üniversite & 100 & 208.92 & & & \\
& Lisansüstü & 25 & 177.04 & & & \\
& Toplam & 439 & & & & \\
\hline
\end{tabular}

Tabloda görüldüğü üzere, örneklemi oluşturan öğrencilerin Ahlâkî Olgunluk Ölçeği puanlarının baba eğitim seviyesi değişkenine göre anlamlı bir farklılık gösterip göstermediğini belirlemek amacıyla 
gerçekleştirilen Kruskal Wallis-H testi sonucunda grupların aritmetik ortalamaları arasındaki fark istatistiksel olarak anlamlı bulunmuştur $\left(x^{2}=9.61 ; s d=4\right) . \mathrm{Bu}$ işlemin ardından Kruskal Wallis-H sonrası bulunan anlamlı farklılığın hangi gruplardan kaynaklandığını belirlemek üzere tamamlayıcı karşılaştırma tekniklerine geçilmiştir. $\mathrm{Bu}$ amaçla kullanılan özel bir test tekniği bulunmadığından ikili karşılaştırmalarda tercih edilen Mann Whitney-U uygulanmıştır. Analizin sonucunda farklılığın babası ilkokul mezunu olanlarla üniversite mezunu olanlar arasında ilkokul mezunu olanların lehine olduğu görülmüştür $(U=823.00 ; z=-2.11)$. Gruplar arasında babası ortaokul mezunu olanlar ile lise mezunu olanlar arasında da ortaokul mezunu olanlar lehine bir fark bulunmuştur $(U=5.14 ; z=-1.990)$. Bunun yanında anlamlı farkl1l1k ortaokul mezunu olanlarla üniversite mezunu olanlar arasında da ortaokul mezunu olanların lehine bulunmuştur $(U=4.15 ; z=-1.975)$. Gruplar arasında babası ortaokul mezunu olanlar ile lisansüstü mezunu olanlar arasinda da ortaokul mezunu olanlar lehine bir fark bulunmuştur $(U=835.50 ; z=-2.504)$.

Tablo 16. Öznel İyi Oluş Ölçeğinden Alınan Puanlarla Ahlâkî Olgunluk Ölçeğinden Alınan Puanlar Arasındaki İlişkiyi Belirlemek Üzere Yapılan Pearson Çarpım Moment Korelasyon Analizi Sonuçları

\begin{tabular}{lccc}
\hline Değişken & $\mathbf{N}$ & $\boldsymbol{R}$ & $\boldsymbol{p}$ \\
\hline $\begin{array}{l}\text { Öznel İyi Oluş } \\
\text { Ahlâkî Olgunluk }\end{array}$ & 442 & .45 & .000 \\
\hline
\end{tabular}

Tablodan da anlaşılacağı üzere, öznel iyi oluş ölçeğinden alınan puanlarla ahlâkî olgunluk ölçeğinden alınan puanlar arasındaki ilişkiyi belirlemek üzere yapılan Pearson Çarpım Moment Korelasyon analizi 
sonucunda puanlar arasında istatistiksel açıdan $\mathrm{p}<.001$ seviyesinde pozitif yönde anlamlı bir ilişki saptanmıştır $(r=-.45 ; p<.001)$.

\section{Sonuç ve Tartışma}

Öznel iyi oluş, bireyin hayatını bilişsel ve duyuşsal olarak değerlendirmesidir. Bu değerlendirmenin yapılabilmesi için bireyin belli bir bilişsel yapıya sâhip olması beklenir. Henüz soyut düşünmeyi gerçekleştiremeyen yahut aklî melekeleri yerinde olmayan bireyin bu değerlendirmeyi sağlıklı bir biçimde yapamayacağı söylenebilir. $\mathrm{Bu}$ araştırmada öznel iyi oluş seviyesinin yaşa göre değişmemesinin sebebi araştırmaya katılan bireylerin benzer gelişimsel özellikler göstermesi olabilir.

Ulloa, Moller ve Sousa-Poza (2013) tarafindan gerçekleştirilen bir araştırmada öznel iyi oluş ile yaş arasındaki ilişki disiplinlerarası bir bakış açısıyla incelenmiş ve bu iki değişken arasında ilişki olup olmadığına dair kesin bir neticeye ulaşılamayacağı sonucuna ulaşılmıştır. Türkiye'de yapılan araştırmalara bakıldığgnda ise genellikle öznel iyi oluş seviyesinin yaşa göre farklılaşmadığı görülmektedir (Özen, 2005; Çevik, 2010; Akgündüz ve Bardakoğlu, 2012). Bu araştırmada da, örneklemi oluşturan lise öğrencilerinin öznel iyi oluş seviyelerinin yaş değişkenine göre anlamlı düzeyde farklılaşmadığı görülmüştür. Akgündüz ve Bardakoğlu (2012) tarafindan meslek lisesi öğrencileriyle gerçekleştirilen bir araştırmada ise meslek lisesine devam eden 9. sınıf ve 12. sınıf öğrencilerinin öznel iyi oluş seviyelerinin farklılaştığı sonucuna ulaşılmıştır. Özen (2005) ve Çelik (2008) 
tarafından yürütülen araştırmada da lise öğrencilerinin öznel iyi oluşlarının sınıf seviyesine göre değişmediği görülmüştür.

Öznel iyi oluşun ilk tanımı, Wilson (1967, akt; Diener, Suh, Lucas ve Smith, 1999) tarafindan yapılmıştır. Wilson'ın tanımı "her cinsiyetten ve zekâ seviyesinden..." ş̧eklinde başlar ve öznel iyi oluş kriterlerinin var oluşu cinsiyetle zekâ seviyesine bağlı olarak değişmez. $\mathrm{Bu}$ araştırmada da öznel iyi oluş açısından cinsiyetler arasında anlamlı bir fark görülmemiştir. Yapılan araştırmalar, öznel iyi oluşun cinsiyete göre farklılık göstermediğini ya da bulunan farklılığın az olduğunu ortaya koymaktadır (Özen, 2005; Çelik, 2008; Rees, Goswami ve Bradshaw, 2010; Aypay ve Eryılmaz, 2011; Akgündüz ve Bardakoğlu, 2012; Long, Huebner, Wedell ve Hills, 2012; Uçan, 2013).

Tesch-Römer, Motel-Klingebiel ve Tomasik (2008) tarafindan çeşitli ülkelerdeki öznel iyi oluş seviyelerinin cinsiyet ve cinsiyet eşitsizliği bağlamında incelendiği araştırmada, cinsiyet değişkeninin öznel iyi oluşu farklılaştırdığı sonucunu veren araştırmaların aksine, toplumsal cinsiyet rollerinin öznel iyi oluş üzerinde etkili olduğu görülmüştür. Bu bakımdan, cinsiyet eşitsizliğinin sınırlarını zorladığı, her gün bir başka kadın cinayetiyle güne uyanılan Türkiye'de lise öğrencilerinin öznel iyi oluş seviyelerinin cinsiyete göre değişmemesi; yani, erkeklerle kadınların benzer düzeyde öznel iyi oluşa sahip oldukları sonucu düşündürücüdür. Bu sonuç, bu bölgede yaşayan lise öğrencilerinin cinsiyet eşitsizliği, kadına şiddet gibi problemlerden mustarip olmayabileceğini yahut yaşları gereği cinsiyet rolleri bakımından ayrışmış olmayabileceklerini akla getirmektedir. 
Konu ve Rimpela (2002), okul modelinin öğrencinin öznel iyi oluşu üzerinde etkili olacağını öne sürmüştür. Öğrencinin okulda öznel iyi oluşunun yüksek olmasında okulun fiziksel çevresi, organizasyon şeması, programlar, sınıf büyüklüğü, güvenlik, okul yemekleri, grup dinamikleri, öğretmen-öğrenci ilişkileri, akran ilişkileri, okulâile işbirliğgi, öğrencinin emeğine değer verme biçimi, rehberlik, öğrenciyi cesaretlendirme, yaratıcılık odaklı eğitim ile öğrencinin sağlık durumunun önemli birer faktör olduğu belirtilmiştir.

Bu araştırmada öğrencilerin Öznel İyi Oluş Ölçeği’nden aldıkları puanlar okul türüne göre değerlendirildiğinde anlamlı bir farklılık ortaya çıkmadığı görülmektedir. Bu bulgu, Soutter (2011) tarafından Yeni Zelanda'da yürütülen araştırma sonuçlarıyla örtüşmektedir. Bu araştırmada öğrenciler, öznel iyi oluş tanımlarını çeşitli değişkenlerle açıklamışlar; ama okulun öznel iyi oluş seviyeleri üzerinde önemli bir etken olmadığını belirtmişlerdir. Bu açıdan bakıldığında, öğrencilerin öznel iyi oluş puanlarının farklılaşmamasının öğrencilerin okul alg1sından ya da okulların benzer özellikler taşımasından kaynaklandığı söylenebilir.

1924 y1lında kabul edilen Tevhid-i Tedrisât Kanunu (Ar1, 2002) ile bütün okullar Millî Eğitim Bakanlığı'na bağlanmıştır. Bu tarihten sonra okulların müfredatları MEB tarafından ortak değerler çatısı altında değerlendirilmeye başlamıştır. Öğrencilerin öznel iyi oluş puanlarının okul türüne göre değişmemesi Tevhid-i Tedrisat'ın bir sonucu olarak değerlendirilebilir. 
Öznel iyi oluş ile gelir seviyesi arasındaki ilişkiyi inceleyen pek çok araştırma vardır. Ramia (2012) tarafindan Avustralya'da gerçekleştirilen araştırmada âilenin gelir durumunun bireyin öznel iyi oluşunu farklılaştırdığı sonucuna ulaşılmıştır. Sacks, Stevenson ve Wolfers (2013) tarafından yapılan araştırmada da çeşitli ülkelerdeki öznel iyi oluş seviyeleri incelenmiş ve zengin insanların fakirlere göre daha umutlu olduklarını ifade ettikleri ve gelir seviyesi arttıkça öznel iyi oluş seviyesinin de arttığı görülmüştür. Canbay (2010) tarafindan Ankara'daki liselerde gerçekleştirilen araştırmada ise öğrencilerin öznel iyi oluş seviyelerinin âile gelir durumuna göre değiştiğgi; gelir seviyesi yüksek âilede yaşayan öğrencilerin öznel iyi oluş puanlarının da yüksek olduğu görülmüştür. Bu araştırmada öznel iyi oluşun âilenin gelir seviyesine göre farkl1lık gösterdiği; düşük ekonomik seviyedeki âileye mensup öğrencilerin yüksek gelir seviyesine sahip âilelerdekilere nazaran daha yüksek öznel iyi oluş seviyesine sahip oldukları görülmüştür. Alanyazında araştırma sonuçlarını teyit edecek şekilde paranın mutluluk getirmediğini vurgulayan araştırmalar bulunmaktadır (Easterlin, 1974; Ahuvia, 2008). Wills ve Hamilton (2007) tarafindan Kolombiya, Brezilya ve Kanada'da yaşayan bireylerin öznel iyi oluşlarının karşılaştırmalı olarak incelendiği bir araştırmada Latin Amerika ülkelerinde düşük sosyoekonomik düzeye rağmen mutluluk düzeylerinin yüksek olduğu sonucuna varılmıştır.

Yapılan araştırmalar, âilenin öznel iyi oluş seviyesi üzerinde önemli bir faktör olduğunu göstermektedir (Rask, Kurki ve Paavlianien, 2003; Joronen ve Kurki, 2005; Aypay ve Eryılmaz, 2011; Wei, Liao, Ku ve Shaffer 2011). Gutman, Brown, Akerman ve Obolenska- 
ya (2010) tarafından Birleşik Krallık'ta gerçekleştirilen araştırmada ebeveynleriyle iyi ilişkisi olan çocukların yüksek, kötü bir ilişkiye sâhip olan çocuklarınsa düşük öznel iyi oluş seviyeleri olduğu görülmüştür. Bu araştırmada da öğrencilerin öznel iyi oluşlarının anne ve babaların eğitim durumları ile hayatta olup olmamalarına göre farkl1laşıp farklılaşmadığı test edilmiştir. Araştırmanın bulguları da öğrencilerin öznel iyi oluşlarının annelerinin eğitim seviyesine göre farkl1laşmadığını göstermektedir. Araştırmada anne eğitim seviyesinin öğrencilerin öznel iyi oluş seviyesini farklılaştırmaması sebebinin incelenmesi esnasında öznel iyi oluşun yüksek olmasının anneden algılanan sevgiyle daha çok ilgili olabileceği düşünülmüş, annenin sevgisini göstermesinin de eğitim seviyesine bağlı olmayabileceği ihtimali üzerinde durulmuştur. Araştırmadan elde edilen bulgulara göre baba eğitim seviyesi de öğrencilerin öznel iyi oluş seviyelerini farklılaştırmamıştır. Bu bulgular, bireyin ruh sağlığ üzerinde anne ve babanın eğitim seviyesinin etkisi olduğu bilgisiyle çelişmektedir.

Cinsiyet ve ahlâkî olgunluk arasındaki ilişki üzerine yapılan tartışmalar yıllardan bu yana süregelmiştir. Yapılan araştırmalar çoğunlukla, kadınların erkeklere nazaran daha yüksek ahlâkî olgunluk seviyesine sahip olduklarını göstermiştir (Donenberg ve Hoffman, 1988; Şengün, 2008). Bu araştırmada da daha önceki bulgulara benzer biçimde öğrencilerin Ahlâkî Olgunluk Ölçeği'nden aldıkları puanlar arasındaki fark kadın öğrencilerin lehine anlamlı bulunmuştur.

Gilligan, kadın ve erkeklerin daha farklı sosyalleştiklerini belirterek, cinsiyete göre ahlâk gelişimi açısından farklılıkların olduğunu 
savunmuştur. Gilligan'a göre, erkekler ahlâkî arayışın temelinde adalet olduğuna, kadınlar ise iletişimdeki özen ve bakımın önemli olduğuna inanırlar (Ekşi, 2006; Milli Eğitim Bakanlığı, 2013). Bu araştırmada kullanılan Ahlâkî Olgunluk Ölçeği'nin ahlâkın davranışsal boyutu üzerinde durduğu hatırlanacak olursa, ölçeğin Gilligan'ın belirttiği gibi iletişime ilişkin davranışları ölçmüş olabileceği düşünülebilir.

Gerson (1998) kadın ve erkeklerin ahlâk bakımından farklılık göstermesini kadının kimlik tanımının sevgi, erkeğin ise iş üzerine kurulu olmasından kaynaklandığını belirtmektedir. Kimliğin oluşmasında ise kültürün etkisi yadsınamaz ölçüde önemlidir. Türkiye kültüründe kadın, erkeğe göre daha naif, anaç, şefkatli yetiştirilirken; erkek, daha rekabetçi bir şekilde yetiştirilmektedir. Rekabetin olduğu ortamda ahlâkî değerlerin uzun süre var olması güçtür. Böylece kadınlar daha çok manevî değerlerle haşır neşir olurken, erkekler ahlâkî değerlerin uzun süre yaşayamayacağı bu rekabet dünyasına adapte olmaktadır. Piaget bu durumu farklı bir biçimde yorumlamıştır. Kız çocuklarının erkek çocuklarına göre daha basit oyun oynadıklarını belirtmiş ve erkeklerin daha karmaşık oyunlar oynaması nedeniyle cinsiyete göre ahlâkî gelişim ile ilgili herhangi bir karşılaştırma yapılamayacağını belirtmiştir (Fleming, 2005).

Maskülen ögeler üzerine kurulmuş Kohlbergian kuramı (Gilligan, 1985) temel alarak hazırlanmış olan bu ölçek sonucunda kadınların ahlâkî açıdan daha yüksek puan almış olmaları ayrıca tartışılması gereken bir husustur. Bu farklılığın kaynakları ölçeğin maddeleri incelendiğinde açıkça belirmektedir. Ölçek, “düşünmek, karar vermek, 
sorumluluk almak" gibi maskülen ifadelerin yanında "sevgi, empati" gibi feminen içerikli maddeleri de içermektedir. Bu bakımdan ölçeğin insanî bir değerlendirme yaptığı ve her iki cinsi ortak bir zeminde değerlendirdiği söylenebilir.

Kaya ve Aydın (2011) tarafindan gerçekleştirilen "Üniversite Öğrencilerinin Dinî İnanç ile Ahlâkî Olgunluk Seviyeleri Arasındaki İlişkinin İncelenmesi" başlıklı makalenin örneklemini On Dokuz May1s Üniversitesi'nde öğrenim gören 606 öğrenci oluşturmaktadır. Araştırma sonuçlarına göre, dinî inanç ile ahlâkî olgunluk seviyesi açısından pozitif yönde anlamlı bir ilişki vardır. Araştırmaya katılan erkek öğrencilerin dinî inanç puanları kadınlarınkinden daha yüksekken, kadınların ahlâkî olgunluk seviyesi puanları erkeklere oranla daha yükssek bulunmuştur. Bu araştırmada da görüldüğü üzere kadınların ahlâkî olgunluk seviyeleri erkeklere oranla daha yüksektir.

Ahlâkî davranışın yapılması gibi, değerlendirilmesi de zihin gelişmesiyle sıkı sıkıya ilgilidir. İnsan, ahlâkî davranışı dünyaya geldikten sonra öğrendiğine göre, öğrendiği şeylerin yaş ve hayat tecrübesi ile değişmesi ve gelişmesi beklenir (Güngör, 1997, s.29). Akyürek (2007)'e göre, bireyin diğer gelişim alanlarıyla ahlâkî gelişimleri arasında bir ilişki vardır. Birey, bilişsel olarak geliştikçe ahlâkî açıdan da gelişmeye devam edecektir. Bu doğrultuda araştırmalar yapan Kohlberg ve Piaget (Kohlberg ve Lawrence, 1958, 1964, 1969, 1973a, 1973b, 1975, 1976, 1978; Kohlberg ve Hersh, 1977; Kohlberg ve Wasserman, 1980; Piaget, 1965, 2004) gibi bilim insanları da insan üzerinde yaptıkları çalışmalarda ahlâkî davranışın, bireyin gelişim 
dönemine göre farklılaştığını ileri sürmüşlerdir. Araştırmadan elde edilen bulgular ise bu bilginin aksine, Ahlâkî Olgunluk Ölçeği’nden alınan puanların yaşa göre farklılaşmadığı sonucunu vermiştir. Ayrıca Şengün (2008) tarafından lise öğrencilerinin ahlâkî olgunluk seviyelerinin incelendiği araştırmada da lise öğrencilerinin ahlâkî olgunluk seviyelerinin yaş değişkenine göre farklılaşmadığ1 sonucuna ulaşılmıştır. Oysa alanyazında yaş ile ahlâkî gelişim arasında pozitif yönde anlamlı bir korelasyon olduğu bilgisine ulaşılmaktadır (Kohlberg, 1958; Piaget, 1965). Bunun yanında, yapılan araştırmalara göre, çocuklar 12-14 yaşından sonra artık büyük insanların mantıklı düşünce sistemini kullanabilecek derecede gelişmiş bir zekâya sâhip bulunmaktadırlar (Güngör, 1997, s.51). Bu araştırmaya katılan öğrencilerin yaşlarının 12-14 yaşlarından büyük olduğu ve 14 ile 20 arasında değiştiği göz önünde bulundurulduğunda, ahlâkî olgunluk seviyelerinin yaş değişkenine göre farklılık göstermemesinin, bu dönemdeki öğrencilerin benzer gelişimsel özellikler göstermesinden kaynaklandığı söylenebilir.

Araştırma bulguları ahlâkî olgunluğun yaşa göre değişmediğini gösterirken farklı sınıf seviyelerinde öğrenim görmekte olan öğrencilerin farklı ahlâkî olgunluk seviyelerine sâhip olduğu görülmüştür. 9. sınıf öğrencilerinin ahlâkî olgunlukları 12. sınıf öğrencilerine göre daha yüksek bulunmuştur. Yani, alınan formal eğitimin ahlâk üzerinde olumsuz bir etki ortaya çıkardığı sonucuyla karşılaşılmaktadır. Alanyazın bu bulgunun aksine eğitim düzeyi arttıkça ahlâkî olgunluk dü- 
zeylerinin de artacağı bilgisini sunmaktadır (Doyle ve O'Flaherty, 2013).

Araştırmadan elde edilen bulguların sınıf seviyesi yükseldikçe ahlâkî olgunluk seviyesinin azaldığını göstermesi, eğitimin niteliğini akla gelmektedir. Türkiye'de hemen hemen her yıl eğitim sisteminde radikal değişikliklere gidilmekte, sürekli ve kararlı bir eğitim yöntemi izlenmemektedir. Yapılandırmacı eğitim yöntemi benimsendiği söylense de kalabalık sınıflar sebebiyle öğretmenler öğrencilerle yeterince ilgilenememekte, müfredâtı yetiştirme çabasında sadece öğretim yapma gâyesi gütmektedirler. Bu gibi aksaklıkların öğrencilerin akademik başarı ve manevî eğitimlerini olumsuz etkilediği söylenebilir.

Araştırmada öğrencilerin ahlâkî olgunluk seviyeleri yaşa göre anlamlı bir farklılık göstermezken, sınıf seviyesine göre 12. sınıf öğrencilerinin aleyhine farklılaşmıştır. Yaş ile sınıf seviyesi değişkenlerine göre yapılan analizlerin farklı sonuçlar vermesi, farklı sınıf seviyelerinde farklı yaşlarda bireylerin eğitim görmeleriyle açıklanabilir. Öğrencilerin sınıflara göre yaşları incelendiğinde; 9. sınıf öğrencilerinin 14-17 yaşları arasında, 12. sınıf öğrencilerinin ise 17-20 yaşları arasında olduğu görülmektedir.

Gazzâlî’ye göre, ahlâk terbiyesinde insan sorumluluğu esastır. Ahlâk; aile, okul, çevre ve bireyin kendi çabaları ile değişmektedir (Çamdibi, 2007). Freud da, iyi ahlâklı bireyin ortaya çıkmasında eğitim ve çevrenin önemini vurgulamıştır (Freud, 1999). Aşağıda, araştırmadaki veriler bu değişkenler açısından incelenerek tartışılmıştır.

Araştırmada ahlâkî olgunluk seviyesinin okul türüne göre farkl1- 
l1k göstermediği bulgusuna ulaşılmıştır. Şengün (2008) tarafindan gerçekleştirilen bir başka araştırmada lise türleri arasında anlamlı bir fark bulunmuştur. Farklılık, imam hatip lisesi öğrencileri ile genel ve anadolu lisesi öğrencileri arasında bulunmuştur. Bu araştırmada fark11lı̆̆ın çıkmaması, araştırmaya imam hatip lisesi öğrencilerinin katılmamasından ve diğer liselerin benzer eğitim ve öğretim sistemlerine sahip oluşlarından kaynaklanıyor olabilir.

Şengün (2006)'ün lise öğrencilerinin ahlâkî yarg1 ve düşünceleri üzerine yapılan araştırmasında da benzer şekilde öğrencinin hayatının çoğunu geçirdiği yerin ahlâkî yargı ve düşünceler üzerinde etkili bir faktör olmadığı görülmüştür. Ancak yine Şengün (2008) tarafından gerçekleştirilen bir başka araştırmada hayatının çoğunu ilçe/kasabada geçiren lise öğrencilerinin ahlâkî olgunluk puan ortalamasının hayat1nın çoğunu şehirde geçiren lise öğrencilerininkinden daha yüksek olduğu görülmüştür. Araştırmadan elde edilen bulgular, öğrencinin hayatının çoğunu geçirdiği yerin ahlâkî olgunluk seviyelerini de farklılaştırmadığını göstermektedir. Öğrencilerin ahlâkî olgunluk seviyelerinin hayatlarının çoğunu geçirdikleri bölgeye göre değişmemesinin sebebi araştırmaya katılan öğrencilerinin hemen hepsinin, hayatlarının çoğunu şehir merkezinde geçirmesiyle açıklanabilir.

Araştırmanın bir diğer problemi de öğrencilerin ahlâkî olgunluk seviyelerinin âilenin gelir durumuna göre değişip değişmediği şeklindeydi. Elde edilen bulgular, öğrencilerin ahlâkî olgunluk seviyelerinin farklı gelir gruplarına göre farklılaşmadığını göstermiştir. Bu bulgu, Şengün (2008) tarafından Samsun'da gerçekleştirilen araştırmanın 
bulgularıyla farklılık göstermektedir. İlgili araştırmada ailesinin ekonomik seviyesini ortanın altı olarak algılayan lise öğrencilerinin ahlâkî olgunluk puan ortalamalarının ailesinin ekonomik seviyesini yüksek olarak algılayan lise öğrencilerine göre daha yüksek olduğu ortaya çıkmaktadır. Üsküdar ilçesinde gerçekleştirilmiş olan araştırmada sosyo-ekonomik duruma göre farklılığın çıkmamasının sebebi sosyoekonomik düzeyin belli bir aralıkta yığılmış olması olarak gösterilebilir. Bunun yanında, araştırma esnasında araştırmacıya yöneltilen sorulardan birçok öğrencinin ailesinin gelir seviyesinden haberdâr olmad1ğ1 bilgisine ulaşılmıştır. Bu durumun da gelir seviyesine göre farkl1laşmanın olmamasına neden olduğu söylenebilir.

Şengün (2008) tarafından gerçekleştirilen araştırmanın verileri, Samsun il merkezindeki liselerde öğrenim gören lise öğrencileriyle yürütülen çalışmada annesinin öğrenim düzeyi ilkokul ve okula gitmemiş olan lise öğrencilerinin ahlâkî olgunluk puan ortalamasının annesinin öğrenim düzeyi lise ve üniversite olan lise öğrencilerinin ortalamasına göre daha yüksek olduğunu göstermektedir. Bu araştırmada ise annenin eğitim seviyesinin öğrencilerin ahlâkî olgunluk seviyesini farklılaştırmadığı sonucuna ulaşılmıştır. Burada da farklılığın ortaya çıkmamasının sebebinin anne eğitim seviyesinin yoğunlukla ilkokul seçeneğinde toplanmış olduğu düşünülmektedir.

Baba eğitim seviyesi ise ahlâkî olgunluk seviyelerini farklılaştırmıştır. Araştırma bulguları incelendiğinde babaların eğitim seviyesinin ilkokul, ortaokul, lise ve üniversite seçenekleri arasında yakın oranlarda dağıldığı görülmektedir. Bu bulgunun en çarpıc1 yanı ise 
baba eğitim seviyesi ile ahlâkî olgunluk arasındaki farklılığın babası ortaokul mezunu olanlarla lise ve üniversite mezunu olanlar arasında ortaokul mezunu olanlar lehine gerçekleşmiş olmasıdır. Burada da ahlâkî olgunluk ile sınıf seviyesi değişkeni arasındaki farklılıklarda olduğu gibi, eğitim seviyesi yükseldikçe çocuğun ahlâkî olgunluğunu olumsuz yönde farklılaştırıyor olması düşündürücü bulunmaktadır. Türkiye'deki eğitim seviyesinin niteliğinin her gün değişmesi ve manevî değerler yerine rekabete dayalı değerler üzerine kurulmuş olmasının bu durumun en önemli sebepleri olduğu düşünülmektedir.

Fârâbî'ye göre mutluluk, ahlâk alanının en merkezî kavramlarından biridir. Bireyler ile milletlerin bu hayatta dünya mutluluğu ve öteki hayatta üstün mutluluğu elde ettikleri insanî nesneleri; nazarî erdemler, düşünme erdemleri, ahlâkî erdemler ve işlek (amelî) erdemler şeklinde sıralamıştır (Topdemir, 2010). Fârâbî Tahsil'de, milletlerin ve şehir insanlarının kendileri ile bu hayatta dünya mutluluğunu, öteki hayatta ise en yüksek mutluluğu elde ettikleri insanî şeyleri dört çeşit olarak sıralar: Nazarî erdemler, fikrî erdemler, ahlâkî erdemler ve amelî sanatlardır (Fârâbî, 1983, akt; Arkan, 2005). Ona göre, mutluluk ancak bu erdemlerin tamamlanmasıyla ortaya çıkar (Fârâbî, 1983, akt; Arkan, 2005). Bu araştırmanın ana problemi de lise öğrencilerinin öznel iyi oluşları ile ahlâkî olgunluk seviyeleri arasında anlamlı bir ilişki olup olmadığı üzerine kuruludur. Araştırmacı ahlâkî olgunlukları yüksek bireylerin öznel iyi oluşları hakkında bilgi edinilip edinilmeyeceği merakıyla araştırmaya başlamıştır. Araştırmadan elde edilen bulgularda Fârâbî'nin belirttiği gibi, öğrencilerin ahlâkî olgunluk se- 
viyeleri ile öznel iyi oluşları arasında pozitif yönde anlamlı bir ilişki olduğu görülmüştür.

Yûsuf Has Hacib, Kutadgu Bilig'te, ancak iyi-faziletli insanın saadete ereceğini, saadetin bireyin iç huzurunun dışa yansıması olduğunu belirtmiştir (Özden, 2007). Araştırmanın sonuçları, Yûsuf Has Hacib'in bu ifadesini doğrular niteliktedir. Edinilen bulgular, öznel iyi oluş ile ahlâkî olgunluk arasında pozitif yönde anlamlı bir ilişki olduğu sonucunu ortaya çıkmıştır. Bu sonuç, öznel iyi oluş yükseldikçe ahlâkî olgunluğun, ahlâkî olgunluk yükseldikçe de öznel iyi oluşun yükseldiğini göstermektedir.

İlk İslâm filozofu olarak tanınan Kindî, ahlâkın, bir mutsuzluğu yenme çabası olduğunu öne sürmüştür. Kindînnin felsefe tarifleri arasında, Sokrates'ten itibaren felsefe ve ahlâkın temel konularından olan, özellikle Müslüman mutasavvıfların ahlâka giriş olarak aldıkları meşhur "insanın kendini bilmesi veya tanıması" ilkesi de yer almıştır (Çağrıcı, 1989, s.39). Kuşkusuz ahlâk ve mutluluk için gerekli olan temel kavram "farkındalık"tır. Kendini bilen ve hayatını sağlam dayanaklara oturtmuş olan bireyin mutlu olması beklenir. Yani, kendini ve hayatını bilişsel ve duyuşsal açıdan değerlendirme kapasitesine sahip (öznel iyi oluşu yüksek) birey, aynı değerlendirme sonucunda ahlâkî erdemlere de yönelecektir.

\section{Kaynakça}

Ahuvia, A. (2008). If money doesn't make us happy, why do we act as if it does? Journal of Economic Psychology, 29, 491-507. 
Akgündüz, Y. ve Bardakoğlu, Ö. (2012). Subjective well-being levels of vocational high school students. Cumhuriyet International Journal of Education, 1(2), 101-107.

Akyürek, P. G. (2007). İlköğretim din kültürü ve ahlak bilgisi derslerinin öğrencilerin ahlaki gelişimine etkisi: Kohlberg'in ahlak gelişimi kuramı açısından bir değerlendirme. Yayımlanmamış yüksek lisans tezi, Erciyes Üniversitesi Sosyal Bilimler Enstitüsü.

Arı, A. (2002). Tevhid-i Tedrisat Kanunu ve laik eğitim. G. Ĕ̈itim Fakültesi Dergisi, 22(2), 181-192.

Arkan, A. (2005, Kasım). Fârâbî'nin gözüyle ahlak-siyaset ilişkilerinin analizi. 2. Siyasette ve Yönetimde Etik Sempozyumu'nda sunulan bildiri, Sakarya.

Aypay, A. ve Eryılmaz, A. (2011). Relationships of high school students' subjective well-being and school burnout. International Online Journal of Educational Sciences, 3(1), 181-199.

Balc1, F. (2011). Psikolojik ve öznel iyi olma hali ile dini inançlar arasındaki ilişki üzerine bir inceleme. Yayımlanmamış Yüksek Lisans Tezi, Uludağ Üniversitesi Sosyal Bilimler Enstitüsü.

Canbay, H. (2010). Lise öğrencilerinin öznel iyi oluş düzeyleri ile sosyal beceri düzeyleri arasındaki ilişkinin incelenmesi, Yayımlanmamış Yüksek Lisans Tezi, Dokuz Eylül Üniversitesi Eğitim Bilimleri Enstitüsü.

Çağrıc1, M. (1989). İslâm düşüncesinde ahlâk. İstanbul: Marmara Üniversitesi İlahiyat Fakültesi Vakfı Yayınları.

Çamdibi, H. M. (2007). Gazzâlî’de ahlâk terbiyesi. R. Kaymakcan ve M. Uyanık, (Ed.), Teorik ve pratik yönleriyle ahlâk içinde (213-251). İstanbul: Değerler Eğitimi Merkezi. 
Çelik, Ş. (2008). Lise öğrencilerinin öznel iyi oluşlarının duygusal zekâ açısından incelenmesi, Yayımlanmamış Yüksek Lisans Tezi, Selçuk Üniversitesi Sosyal Bilimler Enstitüsü.

Çevik, N. (2010). Lise öğrencilerinin öznel iyi oluşlarını yordayan bazı değişkenler, Yayımlanmamış Yüksek Lisans Tezi, Gazi Üniversitesi Eğitim Bilimleri Enstitüsü.

Diener, E. (2006). Frequently answered questions, A primer for reporters and newcomers.

http://internal.psychology.illinois.edu/ ediener/faq.html

Diener, E., Suh, E. M., Lucas, R. E. ve Smith, H. L. (1999). Subjective well-being: Three decades of prograss. Psychological Buleltin, 125(2), 276-302.

Donenberg, G. R. ve Hoffman, L. W. (1988). Gender differences in moral development. Sex Roles, 18(11/12), 701-717.

Doyle, E. ve O'Flaherty, J. (2013). The impact of educational level and type on moral reasoning. Irish Educational Studies, 32(3), 377-393.

http://www.tandfonline.com/doi/abs/10.1080/03323315.2013.82 3273

Easterlin, Richard A. (1974) "Does economic growth improve the human lot?" P. A. David ve M. W. Reder, (Ed.), Nations and households in economic growth: essays in Honor of Moses Abramovitz içinde (89-125). New York: Academic Press. 7 Ocak 2014,

http://graphics8.nytimes.com/images/2008/04/16/business/Easte rlin1974.pdf. 
Ekşi, H. (2006). Bilişsel ahlak gelişimi kuramı: Kohlberg ve sonrası. Abant İzet Baysal Üniversitesi Eğitim Fakültesi Dergisi, 6(1), 29-38.

Fleming, J. S. (2005). Piaget, Kohlberg, Gilligan, and Others on moral development. 15 Ocak 2014, http://swppr.org/Textbook/Ch\%207\%20Morality.pdf.

Freud, S. (1999). Uygarlık, din ve toplum. (S. Budak, Çev.). Ankara: Öteki. (Orijinal çalışma basım tarihi 1926).

Gerson, K. (1998). Moral dilemma, moral strategies, and the transformation of gender. Lessons from two generations of work and family change. Sociologists for Women in Society Feminist Lecture, 16(1), 8-28.

Gilligan, C. (1985). In a different voice: women's conceptions of self and of morality. The Scholar \& Feminist, 30, 1-36.

Gutman, L. M., Brown, J., Akerman, R. ve Obolenskaya, P. (2010). Change in wellbeing from childhood to adolescence: risk and resilience (Rapor No. 34). London: Centre for Research on the Wider Benefits of Learning.

Gündüz, M. (2010). Ahlâk sosyolojisi. Ankara: Anı.

Güngör, E. (1997). Ahlâk psikolojisi ve sosyal ahlâk. İstanbul: Ötüken Yayınları.

Hamurcu, H. (2011). Ergenlerin yetkinlik inançlarl ve psikolojik iyi oluşlarını yordamada psikolojik ihtiyaçlar. Yayımlanmamış Doktora Tezi, Selçuk Üniversitesi Eğitim Bilimleri Enstitüsü.

Joronen, K. ve Kurki, A. (2005). Familial contribution to adolescent subjective well being. International Journal of Nursing Practice, 11(3), 125-133. 
Kaşgarlı, M. (1985). Divan'ü Lugat-it Türk tercümesi II. (B. Atalay, Çev.). Ankara: Türk Dil Kurumu. (Orijinal çalışma basım tarihi 1266).

Kaya, M. ve Aydın, C. (2011). Üniversite öğrencilerinin dini inanç ile ahlaki olgunluk düzeyleri arasındaki ilişkinin incelenmesi. On dokuz Mayıs Üniversitesi İlahiyat Fakültesi Dergisi, 30, 15-42.

Kılıç, R. (2007). İslâm kelam düşüncesinde ahlâk anlayışı. R. Kaymakcan ve M. Uyanı, (Ed.), Teorik ve pratik yönleriyle ahlâk içinde (162-188). İstanbul: Değerler Eğitimi Merkezi.

Kohlberg, L. (1958). The development of modes of moral thinking and choise in the year 10 to 16, Yayımlanmamıs doktora tezi, The University of Chicago.

(1964). Development of Moral Character and Moral Ideology. M. L. Hoffman ve L. W. Hoffman. (Ed.), Review of Child Development Research, Vol. I. içinde (381-431). New York: Russel Sage Foundation.

. (1969). Stage and Sequence: The Cognitive Developmental Approach to Socialization. D. A. Goslin. (Ed.), Handbook of Socialization Theory and Research içinde (347-480). Chicago: Rand McNally.

. (1973a). Continuities in Childhood and Adult Moral Development Revisited. P. B. Baltes and K. W. Schaie (Ed.), Life-span Developmental Psychology: Personality and Socialization içinde (179-204). New York: Academic Press.

. (1973b). The Child as a Moral Philosopher. B. I. Channen ve J. F. Soltis, (Ed.), Moral Education içinde (131-143). New York: Teachers College Press. 
. (1975). Moral education for a society in moral transition. Educational Leadership, 33(1), 46-54.

. (1976). Moral Stages and Moralization: The Cognitive Developmental Approach. T. Lickona, (Ed.), Moral Development and Behavior: Theory, Research and Social Issues. New York: Holt, Rinehart \& Winston.

. (1978). Education for Justice: A Modern Statement of the Platonic View. J. M. Gustafson, (Ed.), Moral Education içinde (56-83). New York: Harvard University Press.

Kohlberg, L. ve Hersh, R. H. (1977). Moral development: a review of the theory. Theory Into Practice, 16(2), 53-59.

Kohlberg, L. ve Wasserman, E. R. (1980). The cognitive-developmental approach and the practicing counselor: An opportunity for counselors to rethink their roles. Personnel and Guidance Journal, 58(9), 559-567.

Konu, A. ve Rimpela, M. (2002). Well-being in schools: A conceptual model. Health Promotion International, 17(1), 79-87.

Long, R. F., Huebner, E. S., Wedell, D., H ve Hills, K. J. (2012). Measuring school-related subjective well-being in adolescents. American Journal of Orthopsychiatry, 82, 50-60.

Longman Sözlük. (1995). Ahlâk. USA: Longman.

Lucas, R. E. ve Diener, E. (1999). Personality and subjective well-being. E. Diener, R. E. Lucas ve D. Kahneman, (Ed.), Well-being: The foundations of hedonic psychology. New York: Russell Sage Foundation. 
Milli Eğitim Bakanlığı. (2013). Çocuk gelişimi ve eğitimi. Ahlak Gelişimi. Ankara: MEB. 01 Mart 2013, http://www.megep.meb.gov.tr/mte_program_modul/moduller_p df/Ahlak\%20Geli\%C5\%9Fimi.pdf.

Özden, H. (2007), Kutadgu Bilig'te ahlak kavramı ve tıp etiğine katkısı. İstanbul: Ötüken Neşriyat.

Özen, Ö. (2005). Ergenlerin öznel iyi oluş düzeyleri. Yayımlanmamış Yüksek Lisans Tezi, Hacettepe Üniversitesi Sosyal Bilimler Enstitüsü.

Piaget, J. (1965). The moral judgement of the child. (M.Gabain, Çev.). New York: The Free Press. http://ia600407.us.archive.org/18/items/moraljudgmentoft00561 $3 \mathrm{mbp} /$ moraljudgmentoft005613mbp.pdf.

2004. Çocukta zihinsel gelişim. (2.bask1). (H. Portakal, Çev.). İstanbul: Cem Yay.

Ramia, I. (2012). The paradox of subjective well-being and tertiary education, An investigation of Australian data using a heterogeneity and life-domain approach. Yayımlanmamış doktora tezi, University of New South Wales.

Rask, K., Kurki, P.A. ve Paavilainen, E. (2003). Adolescent subjective well-being and family dynamics. Scand J.Caring Sci,17,129-138.

Rees, G., Goswami, H. ve Bradshaw, J. (2010). Developing an index of children's subjective well-being in England. UK: The Children's Society. 
Sacks, D. W., Stevenson, B. ve Wolfers, J. (2013). Growth in subjective wellbeing and income over time.

http://www.brookings.edu/ /media/research/files/papers/2013/0 4/subjective-well-being-income/subjective-well-being-income.p df.

Soutter, A. K. (2011). What can we learn about wellbeing in school? Journal of Student Wellbeing, 5(1), 1-21.

Şengün, M. (2006). Lise son sınıf öğrencilerinin ahlaki düşünce ve yargıları. Samsun İli Örneği. Dinbilimleri Akademik Araştırma Dergisi, 6(3), 297-316.

Şengün, M. ve Kaya, M. (2007). Ahlâkî Olgunluk Ölçeği: Geçerlik ve güvenirlik çalışması. Ondokuz Mayıs Üniversitesi Ilahiyat Fakültesi Dergisi, 24(24-25), 51-64.

Şengün, M. (2008). Lise ögrrencilerinin ahlaki olgunluk düzeylerinin bazı kişisel değişkenler açısından incelenmesi. Yayımlanmamış doktora tezi, Ondokuz Mayıs Üniversitesi Sosyal Bilimler Enstitüsü.

Tesch, C. T., Motel-Klingebiel, A. ve Tomasik, M. J. (2008). Gender differences in subjective well-being: Comparing societies with respect to gender equality. Soc Indic Res, 85, 329-349.

Topdemir, H. G. (2010). Fârâbî. İstanbul: Say.

Turiel, E. (2002). The culture of morality: Social development, context, and conflict. Cambridge: Cambridge University Press.

Türkmen, M. (2012). Öznel iyi oluşun yapısı ve anababa tutumları, özsaygı ve sosyal destekle ilişkisi: Bir model sınaması. Uşak Üniversitesi Sosyal Bilimler Dergisi, 5(1), 41-73. 
Uçan, A. (2013). Cinsiyetleri farklı lise öğrencilerinin öznel iyi oluşlarının toplumsal konum ile ilgili risk alma ve göç değişkenlerine göre incelenmesi. Yayımlanmamış yüksek lisans tezi, Mersin Üniversitesi Eğitim Bilimleri Enstitüsü.

Ulloa, L. B. F., Moller, V. ve Sousa-Poza, A. (2013). How does subjective well-being evolve with age? A literature review. Journal of Population Ageing, 6, 227-146.

Wei, M., Liao, K. Y., Ku, T. ve Shaffer, P. A. (2011). Attachment, self-compassion, empathy, and subjective well-being among college students and community adults. Journal of Personality, 79(1), 191- 221.

Wills, E. ve Hamilton, M. (2007). Subjective well-being in cities: A cross-cultural analysis in Bogotá, Belo Horlzonte and Toronto. Economic \& Social Research Council. 